JOANNA SZAFRAN

ORCID 0000-0001-5646-7118

Uniwersytet im. Adama Mickiewicza

$w$ Poznaniu

Olena Hrybiuk

ORCID 0000-0003-3402-0520

Institute of Information Technologies and Learning Tools of NAES

of Ukraine

\title{
WYBÓR DYREKTORA SZKOŁY - WYMAGANIA I PROCEDURA KONKURSOWA W POLSCE I UKRAINIE. W KIERUNKU DOBRYCH PRAKTYK
}

\begin{abstract}
AвSTRACT. Szafran Joanna, Hrybiuk Olena, Wybór dyrektora szkoły - wymagania i procedura konkursowa $w$ Polsce i Ukrainie. W kierunku dobrych praktyk [The Selection of the School Principal - Competition Requirements and Procedure in Poland and Ukraine. Towards Good Practices]. Studia Edukacyjne nr 52, 2019, Poznań 2019, pp. 227-243. Adam Mickiewicz University Press. ISSN 1233-6688. DOI: 10.14746/ se.2019.52.15

Modern school requires modern leaders. These are adequately educated people with necessary skills and ability to perform the responsible work of the principal. These indisputable statements and criteria are not taken into account when selecting school principals; nor are they taken into consideration in the existing competition requirements and procedures for the headmaster's position. The article discusses and analyzes the criteria, provides recommendations to improve existing requirements and procedures. Critical reflection concerns the procedure of choosing a school principal within the framework of the current legal regulation in Poland and Ukraine. Special attention is paid to the requirements and procedures, including the qualification, psychological predisposition and skills of future school principals. The result of a critical analysis of existing standards and the proposal of changes are aimed at a more professional selection of managers in education.
\end{abstract}

Key words: school director, director competency, law on education, competitive procedure 


\section{Wprowadzenie}

Dynamiczna rzeczywistość wymaga od jednostek, jak i całych systemów społecznych nieustannych zmian adaptacyjnych. Odpowiedzialność za właściwe kształtowanie pożądanych postaw i kompetencji spoczywa w znacznej mierze na systemie oświaty, który musi sprostać wielu złożonym społecznogospodarczym wyzwaniom. Aby skutecznie wypełniać swoje zadania, szkoły z reaktywnych i zbiurokratyzowanych instytucji muszą przeobrazić się w organizacje uczące się. Powinny stale doskonalić się we wszystkich aspektach swojego funkcjonowania ${ }^{1}$. Za kompleksową organizację pracy placówki odpowiedzialny jest dyrektor. Nie można jednak urzeczywistnić pożądanej wizji oświaty bez profesjonalnego podejścia do zarządzania i przywództwa edukacyjnego.

$\mathrm{Z}$ tej perspektywy zasadne jest więc zwrócenie uwagi na kompetencje psychologiczne i przygotowanie zawodowe oświatowej kadry kierowniczej. Mając świadomość, iż problematyka przywództwa edukacyjnego stanowi szeroki, wielowymiarowy i złożony temat, $\mathrm{w}$ prowadzonych rozważaniach skoncentrowano się głównie na krytycznej analizie procedur konkursowych i formalnych wymagań stawianych dyrektorom szkół.

Problematyka profesjonalnego podejścia do zarządzania i doboru pracowników na stanowiska zarządcze ma długą historię. Już przeszło 2000 lat p.n.e. w Chinach istniał system selekcji osób pragnących pełnić funkcje urzędnicze w strukturach władzy². Przykład ten wskazuje, że potrzeba identyfikowania kompetencji kierowniczych nie jest niczym nowym, była obecna w świadomości społeczeństw już w przeszłości. Niewątpliwie jednak wraz z procesami i tempem rozwoju społeczno-gospodarczego, coraz więcej uwagi poświęca się efektywności organizacyjnej i powiązanej z nią jakości pracy kierowniczej. Współcześnie niemal na całym świecie intensywnie rozwijają się różnorodne metody i narzędzia doboru kadry menadżerskiej̉, a wyspecjalizowane firmy zajmują się poszukiwaniem i oceną kandydatów na stanowiska kierownicze ${ }^{4}$.

${ }^{1}$ A.J. Jeżowski, J. Madalińska-Michalak, Dyrektor szkoły - koncepcje i wyzwania. Między teoria i praktyka, Warszawa 2015; R. Dorczak, G. Mazurkiewicz (red.), Przywództwo edukacyjne. Próba zmiany, Kraków 2015; K. Gawroński, A. Stefan, Zarządzanie placówką oświatowa, Warszawa 2008; S. Witek, Zarządzanie zreformowana szkota, Warszawa 2000.

${ }^{2}$ Chcąc utrzymać się na stanowisku, co trzy lata urzędnicy przechodzili kolejny egzamin weryfikacyjny，北青网，(2017-11-09). 138万人通过国考审核创7年之最 119个职位无人报 -http:// sh.qihoo.com/pc/detail?url=http\%3A\%2F\%2Ffawen.news.so.com\%2F510609c45eb2013eaeb6f46dca86ea84\&check=b88c8741e6addfa5\&uid =e325af10fcd8b9544de33cc9643032f9\&sign=360_79aabe15.

${ }^{3}$ И. Масааки, Кайдзен: ключ к успеху японских компаний. М.: ЮНИТИ - ДАНА, 2004, AT\&T - http://about.att.com/content/csr/home/possibilities/at-t-aspire.html

${ }^{4}$ Tame, s. 98. 
Wolnorynkowy świat korporacji dawno już dostrzegł znaczenie indywidualnego potencjału jednostki i jego wpływu na prorozwojowe funkcjonowanie całej organizacji ${ }^{5}$. W oświacie kwestia przygotowania i weryfikacji kompetencji kierowniczych, zwłaszcza w wymiarze predyspozycji psychologicznych liderów, jest traktowana powierzchownie i sprowadza się głównie do kontroli posiadanych kwalifikacji formalnych.

Zarówno w Polsce, jak i Ukrainie problem profesjonalnego podejścia do wyboru właściwych ludzi na stanowiska dyrektorów szkół nadal pozostaje nierozwiązany. Ma to związek między innymi z dużymi trudnościami spowodowanymi niedostatecznym opracowaniem wskaźników, kryteriów i metod oceny, koniecznych i pożądanych cech zawodowych potencjalnych dyrektorów szkół ${ }^{6}$. Problem dotyczy też monitorowania rzeczywistych możliwości i efektów pracy obecnie zarządzających. Jest jednak skąd czerpać. Wskazówki dotyczące specyfiki zarządzania w oświacie, funkcji, zadań i wymagań stawianych dyrektorom polskich i ukraińskich szkół, które służyć mogą opracowaniu spójnych, profesjonalnych i adekwatnych procedur konkursowych, odnajdujemy między innymi w publikacjach takich autorów, jak: Yu Babanskij, S. Batyszew, G. Gabdullin, R. Szakurow, T. Szamowa, R. Dorczak, G. Mazurkiewicz, S.M. Kwiatkowski, T. Komorowski, J. Pielachowski, K. Gawroński, czy L. Gawrecki?

${ }^{5}$ S. Banaszak, Edukacja menedżerska w społeczeństwie współczesnym. Studium teoretyczno-empiryczne, Poznań 2011.

${ }^{6}$ S.M. Kwiatkowski, Kwalifikacje zawodowe nauczycieli - wciąż otwarty problem badawczy, Edukacja, 2004, nr 4, s. 26-32; K. Gawroński, Potyczki prawne dyrektora szkoty. Rola prawa w wybranych obszarach zarzadzania szkota, Warszawa 2010; S.M. Kwiatkowski, Problemy terminologiczne w procedurach standaryzacji kwalifikacji zawodowych, [w:] Kwalifikacje zawodowe na wspótczesnym rynku pracy, red. S.M. Kwiatkowski, Warszawa 2004, s. 7-15.

${ }_{7}$ W pracach G. Gabdullina, M. Bershadskiego, Ya.A. Kamenskiego, V. Suchomlynskiego, Ye. Yamburga omówione są różne strony kierowniczej działalności dyrektorów szkół. Aspekty psychologiczne pracy dyrektorów szkół przeanalizowane są w pracach A. Tieriechowa, A. Tonkonogowa, A. Szakurowa. Pytania dotyczące podnoszenia kwalifikacji dyrektorów szkól, doskonalenia ich mistrzostwa zawodowego były przedmiotem badań Ya.A. Kamenskiego, V. Suchomlynskiego, Ye. Yamburga. Opracowaniu wymogów co do cech zawodowych i osobowo-biznesowych dyrektora szkoły poświęcone były prace W. Afanasjewa, A. Berga, A. Omarowa, G. Popawa i innych. Г.Г. Габдуллин, Школоведение. Курс лекиий по педагогике, Казань 1997, с. 231; Е.А. Ямбург, Отсутствие грамотной стратегии образования - угроза национальной безопасности // Народное образование, 2012, 6, с. 39-45; А.М. Каменский, Директор школы - ключевая фигура педагогических инноваций; В.О. Сухомлинський, Вибрані твори в 5-ти т. t. 4. / В.О.Сухомлинський, Київ; S.M. Kwiatkowski, Problemy; K. Gawroński, Potyczki prawne dyrektora szkoty; L. Gawrecki, Kompetencje menedżera oświaty. Poradnik dla dyrektorów szkót $i$ innych placówek edukacyjnych oraz pracowników prowadzacych i nadzorujących, Poznań 2003; T. Komorowski, Dyrektor szkoły. Pracodawca, menedżer, pracownik, Poznań 2008; J. Pielachowski, Organizacja, kierowanie i nadzór pedagogiczny w szkole. Poradnik dla dyrektorów szkół oraz pracowników organów prowadzacych i nadzorujących szkoły, Poznań 2009; G. Mazurkiewicz, Przywództwo edukacyjne. Odpowiedzialne zarządzanie edukacją wobec wyzwań wspótczesności, 


\section{Jak zostać dyrektorem?}

Jak wskazano powyżej, nie brakuje opracowań naukowych służących wypracowaniu pożądanego modelu przywództwa edukacyjnego. Problem dotyczy raczej przetransponowania naukowej wiedzy teoretycznej na politykę oświatową, a w konsekwencji także na praktykę konkursową tak, by służyła rzeczywistej weryfikacji posiadanych kompetencji. W rozwiązaniach proceduralnych, zarówno w Polsce jak i Ukrainie, dużą wagę przywiązuje się do formalności, a zbyt małą do profesjonalnej diagnozy profilów psychologicznych, umiejętności kierowniczych i predyspozycji przywódczych. W opinii autorek jest to błąd, gdyż obok koniecznych kwalifikacji zawodowych, dyrektorzy powinni cechować się określonymi umiejętnościami, umożliwiającymi im skuteczne i sprawne wykonywanie powierzonych zadan. Wydaje się, że rozpoznanie i ocena właściwości psychologicznych oraz menadżerskich już podczas konkursu na stanowisko dyrektora (stanowiąca element konieczny procesu rekrutacyjnego), będzie przejawem holistycznego i odpowiedzialnego spojrzenia na funkcje szkoły oraz jakość procesów w niej zachodzących. Współczesność wyznacza szkole wiele zadań, toteż aby mogła im sprostać, potrzebuje rzeczywistych przywódców. O skuteczności dyrektora trudno wnioskować jedynie na podstawie uzyskanych w toku nauki dyplomów. Z kolei, o sukcesie lub porażce placówki świadczą nie tylko kwestie administracyjne, czy miejsce placówki w rankingu szkół, ale także klimat organizacji, komunikacja, poziom motywacji pracowników i uczniów, poczucie celu, wizja, misja i tym podobne. Za te i wiele innych elementów nowoczesnego zarządzania w znacznej mierze odpowiada w szkole dyrektor. Kto zatem może nim zostać i jakie kryteria powinien spełnić kandydat, aby mógł właściwie wywiązywać się z powierzonej funkcji?

\section{Regulacje prawne. Wymagania i konkurs dyrektorski w Polsce}

Od wielu lat polska oświata przeżywa burzliwy okres reform, zarówno w wymiarze ogólnosystemowym jak i wewnątrzorganizacyjnym. W efekcie tych zmian, dyrektor zyskał większe uprawnienia zarówno w kwestiach kadrowych, jak i organizacyjnych, poszerzył się zakres jego obowiązków, a co za tym idzie - także odpowiedzialności ${ }^{8}$. Wobec wielu nowych wyzwań,

Kraków 2011; R. Dorczak, G. Mazurkiewicz (red.), Przywództwo edukacyjne; G. Mazurkiewicz (red.), Jak budować dobrą szkołę? Potencjał i bariery ewaluacji, Kraków 2015.

8 T. Komorowski, Dyrektor szkoty, s. 115-116 i 285-288; J. Szafran, Zarzadzanie w oświacie a kompetencje psychologiczne dyrektorów, Zarządzanie Publiczne, 2018, 1(41), s. 93. 
z którymi przyjdzie się mierzyć dyrektorom szkół w toku wykonywania codziennych obowiązków zawodowych, pojawia się pytanie o kwalifikacje i kompetencje osób ubiegających się o to stanowisko.

Zasadnicze kwestie związane $\mathrm{z}$ wymogami wobec dyrektora zawiera Rozporządzenie Ministra Edukacji Narodowej z 11 sierpnia 2017 roku9. Zgodnie $\mathrm{z}$ tym dokumentem ${ }^{10}$ :

§ 1. Stanowisko dyrektora publicznego przedszkola, publicznej szkoły podstawowej i publicznej szkoły ponadpodstawowej, zwanych dalej „szkołami", oraz publicznej placówki może zajmować nauczyciel mianowany lub dyplomowany, który spełnia łącznie następujące wymagania:

1) posiada wykształcenie wyższe i tytuł zawodowy magister, magister inżynier lub równorzędny, oraz przygotowanie pedagogiczne i kwalifikacje do zajmowania stanowiska nauczyciela w danym przedszkolu, szkole lub placówce;

2) ukończył studia wyższe lub studia podyplomowe $z$ zakresu zarządzania albo kurs kwalifikacyjny z zakresu zarządzania oświatą prowadzony zgodnie z przepisami w sprawie placówek doskonalenia nauczycieli;

3) posiada co najmniej pięcioletni staż pracy pedagogicznej na stanowisku nauczyciela lub pięcioletni staż pracy dydaktycznej na stanowisku nauczyciela akademickiego;

4) uzyskał:

a) co najmniej dobrą ocenę pracy $\mathrm{w}$ okresie ostatnich pięciu lat pracy lub

b) pozytywną ocenę dorobku zawodowego $\mathrm{w}$ okresie ostatniego roku albo

c) w przypadku nauczyciela akademickiego - pozytywną ocenę pracy $\mathrm{w}$ okresie ostatnich czterech lat pracy w szkole wyższej - przed przystąpieniem do konkursu na stanowisko dyrektora, a w przypadku, o którym mowa w art. 63 ust. 11 i 12 ustawy z 14 grudnia 2016 r. - Prawo oświatowe, jeżeli nie przeprowadzono konkursu - przed powierzeniem stanowiska dyrektora;

5) spełnia warunki zdrowotne niezbędne do wykonywania pracy na stanowisku kierowniczym;

6) ma pełną zdolność do czynności prawnych i korzysta z pełni praw publicznych;

${ }_{9}^{9}$ Na podstawie art. 62 ust. 4 ustawy z 14 grudnia 2016 r. - Prawo oświatowe (DzU z 2017 r., poz. 59 i 949), Rozporządzenie Ministra Edukacji Narodowej z 11 sierpnia 2017 r. w sprawie wymagań, jakim powinna odpowiadać osoba zajmująca stanowisko dyrektora oraz inne stanowisko kierownicze w publicznym przedszkolu, publicznej szkole podstawowej, publicznej szkole ponadpodstawowej oraz publicznej placówce, http://dziennikustaw.gov.pl/du/2017/1597/1 [dostęp: 10.05.2018], poz 1597.

${ }^{10}$ Przytoczenie dość obszernego fragmentu wspomnianego Rozporządzenia wydaje się zasadne w celu lepszego zobrazowania podejścia i priorytetów władz w kwestii podstawowych wymagań stawianych dyrektorom. 
7) nie był prawomocnie ukarany karą dyscyplinarną, o której mowa w art. 76 ust. 1 ustawy z 26 stycznia 1982 r. - Karta Nauczyciela (DzU z 2017 r. poz. 1189), a w przypadku nauczyciela akademickiego - karą dyscyplinarną, o której mowa w art. 140 ust. 1 ustawy z 27 lipca 2005 r. - Prawo o szkolnictwie wyższym (DzU z 2016 r. poz. 1842, z późn. zm.), oraz nie toczy się przeciwko niemu postępowanie dyscyplinarne;

8) nie był skazany prawomocnym wyrokiem za umyślne przestępstwo lub umyślne przestępstwo skarbowe;

9) nie toczy się przeciwko niemu postępowanie o przestępstwo ścigane z oskarżenia publicznego;

10) nie był karany zakazem pełnienia funkcji związanych z dysponowaniem środkami publicznymi, o którym mowa w art. 31 ust. 1 pkt 4 ustawy z 17 grudnia 2004 r. o odpowiedzialności za naruszenie dyscypliny finansów publicznych (DzU z 2017 r. poz. 1311);

11) w przypadku cudzoziemca - posiada znajomość języka polskiego poświadczoną na zasadach określonych w ustawie z 7 października 1999 r. o języku polskim (DzU z 2011 r. poz. 224 i 455, z 2015 r. poz. 1132 oraz z 2017 r. poz. 60).

Kwestie procedur konkursowych określa natomiast Rozporządzenie w sprawie regulaminu konkursu na stanowisko dyrektora publicznego przedszkola, publicznej szkoły podstawowej, publicznej szkoły ponadpodstawowej lub publicznej placówki oraz trybu pracy komisji konkursowej ${ }^{11}$. Na podstawie art. 63 ust. 20 ustawy z 14 grudnia 2016 r. - Prawo oświatowe (DzU z 2017 r. poz. 59 i 949) zarządzono, iż konkurs ogłasza organ prowadzący przedszkole, szkołę lub placówkę. Ogłoszenie zawiera:

1) oznaczenie organu prowadzącego publiczne przedszkole, publiczną szkołę lub publiczną placówkę;

2) nazwę i adres publicznego przedszkola, publicznej szkoły lub publicznej placówki, których dotyczy konkurs;

3) wskazanie wymagań wobec kandydatów na stanowisko dyrektora publicznego przedszkola, publicznej szkoły lub publicznej placówki, określonych w przepisach wydanych na podstawie art. 62 ust. 4 ustawy z 14 grudnia 2016 r. - Prawo oświatowe;

4) wskazanie wymaganych dokumentów:

a) uzasadnienia przystąpienia do konkursu oraz koncepcji funkcjonowania i rozwoju publicznego przedszkola, publicznej szkoły lub publicznej placówki,

b) życiorysu z opisem przebiegu pracy zawodowej, zawierającego w szczególności informację o:

${ }^{11}$ DzU 2017, poz. 1587. 
- stażu pracy pedagogicznej - w przypadku nauczyciela albo

- stażu pracy dydaktycznej - w przypadku nauczyciela akademickiego, albo

- stażu pracy, w tym stażu pracy na stanowisku kierowniczym - w przypadku osoby niebędącej nauczycielem,

Kandydat musi także wykazać się poświadczeniami wszystkich wymaganych dokumentów kwalifikacyjnych oraz złożyć oświadczenie zawierające dane osobowe. Rozporządzenie reguluje również informacje o sposobie i terminie składania ofert oraz sposobie powiadomienia kandydatów o terminie i miejscu przeprowadzenia postępowania konkursowego. W myśl zapisów Rozporządzenia, to organ prowadzący wyznacza przewodniczącego komisji konkursowej, który kieruje jej pracami. Przewodniczący ustala termin i miejsce posiedzenia komisji, o czym powiadamia pisemnie $\mathrm{w}$ postaci papierowej (w uzasadnionych przypadkach w elektronicznej) pozostałych członków komisji oraz kandydatów (nie później niż 7 dni przed terminem posiedzenia). Posiedzenie odbywa się nie później aniżeli w ciągu 14 dni roboczych od upływu terminu składania ofert przez kandydatów, wskazanego w ogłoszeniu konkursu. Prace komisji są prowadzone, jeżeli w posiedzeniu bierze udział co najmniej 2/3 jej członków. Komisja, na podstawie złożonej oferty, podejmuje uchwałę o dopuszczeniu lub odmowie dopuszczenia kandydata do postępowania konkursowego. Uchwała zapada zwykłą większością głosów w głosowaniu jawnym ${ }^{12}$. Komisja podejmuje uchwałę o odmowie dopuszczenia kandydata do postępowania konkursowego, jeżeli nie dopełniono kwestii formalnych lub kandydat nie spełnia wskazanych wymagań.

Wstępne czynności selekcyjne odbywają się bez udziału kandydatów. Po ich zakończeniu przewodniczący komisji informuje kandydatów o dopuszczeniu albo odmowie dopuszczenia do dalszego postępowania konkursowego ${ }^{13}$.

Kolejnym etapem konkursu jest rozmowa kwalifikacyjna. Po ocenie wystąpień kandydatów, komisja (bezwzględną liczbą głosów) wyłania osobę na stanowisko dyrektora w głosowaniu tajnym (każdy członek komisji dysponuje jednym głosem). Rozporządzenie reguluje też kwestie nierozstrzygnięcia konkursu, a także protokołowanie procedury. Po zakończeniu obrad przewodniczący komisji niezwłocznie powiadamia organ prowadzący publiczne misji.

${ }^{12} \mathrm{~W}$ przypadku równej liczby głosów, głos decydujący należy do przewodniczącego ko-

${ }^{13}$ Kandydat, któremu odmówiono dopuszczenia do postępowania konkursowego może, $\mathrm{w}$ terminie 3 dni od otrzymania ustnej informacji o odmowie dopuszczenia do postępowania konkursowego, wystąpić z pisemnym wnioskiem o podanie przyczyn odmowy. Przewodniczący komisji informuje kandydata pisemnie o przyczynach odmowy dopuszczenia do postępowania konkursowego w terminie 7 dni od dnia złożenia wniosku. 
przedszkole, publiczną szkołę lub publiczną placówkę o wyniku konkursu oraz przekazuje temu organowi dokumentację postępowania konkursowego. Organ prowadzący zatwierdza konkurs albo w przypadku stwierdzenia określonych w Rozporządzeniu uchybień unieważnia go. Stanowisko dyrektora powierza się na 5 lat, po których wprowadzono konieczność przeprowadzenia ponownego konkursu ${ }^{14}$.

Analizując powyższe regulacje, można wnioskować o kierunku i priorytetach towarzyszących pracom legislacyjnym. Z przytoczonych dość obszernie dokumentów wynika, że prawodawca przyłożył wielu starań do formalizacji procedury konkursowej, gdzie kwestie trybu postępowania i uzyskanych kwalifikacji zawodowych stanowiły zasadnicze punkty ciężkości. Natomiast, problem określonych (koniecznych czy pożądanych) właściwości psychologicznych do pełnienia funkcji menadżerskiej w oświacie nie znalazł odzwierciedlenia zarówno w wymaganiach stawianych kandydatom, jak i samej metodzie sprawdzającej. Nie wskazano też wymiernych kryteriów czy narzędzi służących weryfikacji zasadniczych obszarów dyrektorskiej profesji w praktyce. Przywołane zapisy jednoznacznie pokazują, że brakuje w świadomości osób stanowiących prawo perspektywy ilościowej i jakościowej związanej $\mathrm{z}$ oceną fundamentalnych umiejętności menadżerskich i predyspozycji psychologicznych przyszłych dyrektorów szkół.

Wydaje się, że w obecnym stanie prawnym najbardziej obiecującym elementem procedury konkursowej, który choć w części może niwelować owe braki, jest (funkcjonujący także wcześniej) etap rozmów z kandydatami. W Rozporządzeniu istnieje zapis, że komisja ma możliwość zadawania pytań, a "po rozmowie z każdym z kandydatów, dokonuje ich merytorycznej oceny”. Podczas tego spotkania można by rzeczywiście zbadać właściwości osobowościowe i zarządcze kandydatów (choć niewątpliwie bardziej rzetelne byłoby użycie wystandaryzowanych narzędzi diagnostycznych). Pojawia się tu jednak zasadnicza wątpliwość, jakie kwalifikacje, kompetencje i eksperckie uprawnienia posiadają sami członkowie komisji. Zapisy nie regulują tych kwestii. Właściwie poza kryterium „przynależnościowym” nie ma innych wymogów określających skład komisji ${ }^{15}$. Jak zatem ma ona zweryfikować predyspozycje osobowościowe czy kierownicze pretendenta, skoro sami jej członkowie nie muszą posiadać wiedzy i umiejętności z tego zakresu. W efekcie także ten etap wyłaniania przyszłego dyrektora opiera się na mało transparentnych, subiektywnych kryteriach oceny. Podczas prowadzonej z kandydatem rozmo-

${ }^{14} \mathrm{~W}$ uzasadnionych przypadkach można powierzyć to stanowisko na krótszy okres, jednak nie krótszy niż 1 rok szkolny; Art. 63, ust. 21, DzU 2018, poz. 996 (DzU 2017, poz. 59).

${ }_{15}$ Skład komisji: po trzech przedstawicieli organu prowadzącego i organu sprawującego nadzór; po dwóch przedstawicieli rady pedagogicznej i rady rodziców; po jednym przedstawicielu zakładowych organizacji związkowych. 
wy, ewaluacji podlega w szczególności przedstawiona przez niego koncepcja funkcjonowania i rozwoju publicznego przedszkola, publicznej szkoły lub publicznej placówki. Niestety, analiza większości dostępnych "planów rozwoju” wskazuje na ich zbyt ogólny, powierzchowny, często odrealniony i życzeniowy charakter. Można oczywiście promować wizjonerstwo, jednak kiedy zaprezentowany plan nie jest $\mathrm{w}$ żaden sposób weryfikowany w przyszłości i jego użyteczność może się zakończyć wraz z wygranym konkursem, wówczas taki element procedury rekrutacyjnej traci swój zasadniczy sens.

\section{Regulacje prawne. Wymagania i procedura konkursowa w Ukrainie}

Zasady ustalone przez Zarządzenie Gabinetu Rady Ministrów Ukrainy $\mathrm{Nr} 827$ „O ustaleniach kolejności mianowania na funkcję kierowniczą państwowych szkół ogólnokształcących"16 przewidują wybór kierowników (dyrektorów) państwowych szkół ogólnokształcących na podstawie konkursu. Jego efektem jest zawarcie kontraktu z osobą, która uzyskała najlepszy wynik. W Ukrainie do szkół ogólnokształcących zalicza się szkoły, szkoły-internaty, sanatoryjne szkoły specjalne 1-3 stopnia; gimnazja, kolegia 2-3 stopnia; licea 3 stopnia; centra szkolno-rehabilitacyjne i tym podobne (artykuł 9 Ustawy z 13.05.99 r. Nr 651-XIV „O ogólnym kształceniu średnim”) ${ }^{17}$. Warto zaznaczyć, że wcześniej nominacja na podstawie konkursu przewidziana była wyłącznie na stanowiska pracowników pedagogicznych gimnazjów (gimnazjów-internatów), liceów (liceów-internatów), kolegiów (kolegiów-internatów), szkół specjalistycznych z rozszerzonym nauczaniem wyznaczonych przedmiotów (Regulamin o szkole ogólnokształcącej zatwierdzony zarządzeniem Rady Ministrów Ukrainy z 27.08.10 Nr 778) ${ }^{18}$.

Zasady przeprowadzenia odpowiednich konkursów są opracowane przez szkoły i zatwierdzane przez organ kierujący oświatą.

${ }^{16}$ Постанова Кабінету Міністрів України від 13 жовтня 2015 р. № 827 «Про затвердження Порядку призначення на посаду керівників загальноосвітніх навчальних закладів державної форми власності». Точка доступу - https://www.kmu.gov.ua/ua/ npas/248564119

17 Закон України від 13.05.1999 р. № 651-XIV «Про загальну середню освіту» (Відомості Верховної Ради України (ВВР), 1999, № 28, ст.230). Документ 651-14, чинний, поточна редакція - Редакція від 28.09.2017, підстава 2145-19. Точка доступу - http:/ /zakon3.rada. gov.ua/laws/show/651-14

18 Постанова Кабінету Міністрів України від 27.08.2010 № 778 «Про затвердження Положення про загальноосвітній навчальний заклад». Перелік Документ 778-2010-п, чинний, поточна редакція - Редакція від 12.08.2017, підстава 576-2017-п. Точка доступу http:/ / zakon3.rada.gov.ua/laws/show/778-2010-\%D0\%BF 
Tryb Postępowania zgodny ze wspomnianym Zarządzeniem Nr 827 określa wymagania na stanowisko kierującego instytucją oświatową dotyczące stażu pracy pedagogicznej, posługiwania się językiem ojczystym, stanu zdrowia. Dokument ma brzmienie: „Kierującym instytucją oświatową może być osoba będąca obywatelem Ukrainy, swobodnie władająca językiem państwowym (ojczystym) i posiadająca wykształcenie wyższe pedagogiczne na poziomie specjalisty lub magistra, staż pracy pedagogicznej nie mniejszy niż trzy lata, właściwe zasady moralne i stan zdrowia, który umożliwia wykonywanie obowiązków zawodowych". Wymagania te są zgodne z normami art. 24 Ustawy Nr 651 i Statutu Nr 778.

Zgodność zajmowanego stanowiska pracowników pedagogicznych szkół (instytucji) ogólnokształcących, także kierowników, jest określana w trakcie ich uwierzytelniania (atestacji) jeszcze przed powierzeniem stanowiska (art. 27 Ustawy Nr 651) ${ }^{19}$.

Zgodnie z punktem 4 Trybu Postępowania Nr 827, decyzją Ministerstwa Nauki i Oświaty Ukrainy lub innego organu centralnego władzy wykonawczej, pod które podlega instytucja oświatowa, w szczególnych przypadkach (np. utworzenie nowej placówki, wakat na stanowisku kierującego, rozwiązanie umowy o pracę z kierującym) przeprowadza się konkurs, ogłaszając ten fakt $\mathrm{w}$ środkach masowej informacji.

W punkcie 6 Trybu Postępowania Nr 827 wskazuje się, że procedurę konkursową przeprowadza komisja konkursowa, w której skład wchodzą przedstawiciele tej instytucji, grona pedagogicznego, stowarzyszeń rodziców, organu miejscowego samorządu. Członkom komisji stawia się również szereg wymagań. Przede wszystkim, w skład komisji nie mogą wchodzić osoby niesamodzielne lub o ograniczonej samodzielności, mające wyrok za dokonanie przestępstwa, jeśli wyrok nie uległ zatarciu lub osoby te nie zostały uniewinnione w procesie sądowym oraz osoby, na które w ciągu ostatniego roku nałożono karę administracyjną za korupcyjne naruszenie prawa. Członkiem komisji nie może być również osoba z rodziny uczestnika konkursu lub przejawiająca konflikt interesów - zgodnie z Ustawą Ukrainy „O zapobieganiu korupcji" ${ }^{20}$. Mie ma jednak żadnych określonych kryteriów dotyczących ich merytorycznych, eksperckich kwalifikacji.

${ }^{19}$ Stały regulamin atestacji pracowników pedagogicznych zatwierdziło Ministerstwo Nauki i Oświaty Ukrainy (0.10.10 r. nr 930), Наказ Міністерства освіти і науки України від 06.10.2010 № 930 «Про затвердження Типового положення про атестацію педагогічних працівників». Документ z1255-10, чинний, редакція від 30.09.2013, підстава z1417-13. Точка доступу - http://zakon5.rada.gov.ua/laws/show/z1255-10

20 Закон України від 14.10.2014 № 1700-VII «Про запобігання корупції» (Відомості Верховної Ради (ВВР), 2014, № 49, ст.2056). Документ 1700-18, чинний, поточна редакція - Редакція від 03.08.2017, підстава 2136-19. Точка доступу - http://zakon3.rada.gov.ua/ laws/show/1700-18 
Kandydat na stanowisko dyrektora, oprócz dokumentów potwierdzających spełnienie wymogów formalnych, składa list motywacyjny oraz perspektywiczny plan rozwoju placówki. Powinien także udowodnić znajomość zasad prawnych ${ }^{21}$ i przejść rozmowę kwalifikacyjną. Kandydaci są zobowiązani złożyć odpowiednie dokumenty w terminie 20 - 30 dni od dnia ogłoszenia konkursu.

Komisja konkursowa ma obowiązek przejrzeć złożone dokumenty oraz przekazać kandydatowi na stanowisko oraz Ministerstwu Nauki i Oświaty Ukrainy lub innemu organowi centralnemu władzy wykonawczej przeprowadzającemu konkurs wyniki i wnioski z tego konkursu.

Rezultaty konkursu, zgodnie z Trybem ${ }^{22}$, są publikowane w środkach masowej informacji, na oficjalnej stronie internetowej Kuratorium Oświaty oraz na stronie placówki oświatowej ${ }^{23}$.

Procedura konkursowa dobiega końca wraz z zawarciem umowy z wybraną osobą. Umowa ta jest zawarta przez organ władzy wykonawczej tego rejonu, pod który podlega dana placówka. Jeśli, według wniosków komisji, konkurs nie przyniósł rozstrzygnięcia, ogłaszany jest powtórny.

Dyrektor wybrany na drodze konkursu może pracować w jednej szkole dwie kadencje, to jest 12 lat. Po tym czasie może kierować inną szkołą lub przejść na inne stanowisko. Dyrektorzy mogą sami wyznaczać swoich zastępców i skład rady pedagogicznej.

Co istotne, miejscowe organy samorządowe powinny określić procedury wyboru kierujących państwowymi placówkami oświatowymi zgodnie z wynikami konkursu, jak określa to Tryb Postępowania Nr 827. Również artykuł 26 Ustawy nr 651 przewiduje nominację na funkcję kierowniczą i zwolnienie z niej przez organy kierujące oświatą.

W praktyce procedura wyboru dyrektorów szkól, tak jak dawniej, przeprowadzana jest drogą heurystyczną, bez szczegółowej analizy zdolności i moż-

${ }^{21}$ Постанова Кабінету Міністрів України від 13 жовтня 2015 р. № 827 «Про затвердження Порядку призначення на посаду керівників загальноосвітніх навчальних закладів державної форми власності». Точка доступу - https://www.kmu.gov.ua/ua/ npas/248564119; Закон України від 13.05.1999 р. № 651-XIV «Про загальну середню освіту» (Відомості Верховної Ради України (ВВР), 1999, № 28, ст.230). Документ 651-14, чинний, поточна редакція - Редакція від 28.09.2017, підстава 2145-19. Точка доступу - http://zakon3.rada.gov.ua/laws/show/651-14

${ }^{22}$ Постанова Кабінету Міністрів України від 27 грудня 2017 р. № 1094 «ро затвердження Порядку проведення конкурсу на зайняття посади керівника державного, комунального закладу охорони здоров'я». Документ 1094-2017-п, чинний, поточна редакція - Редакція від 05.05.2018, підстава 316-2018-п. Точка доступу - http://zakon3. rada.gov.ua/laws/show/1094-2017-\%D0\%BF

${ }^{23}$ Może się zdarzyć, że kandydat nie zgadza się z wynikami komisji, wówczas w ciągu pięciu dni od daty otrzymania wyniku może złożyć odwołanie od decyzji. W razie uchybień postanowienie komisji może być zaskarżone w sądzie. 
liwości kandydatów. Subiektywna ocena potencjalnych kandydatów na kierowników, opierająca się przede wszystkim na doświadczeniu życiowym oraz intuicji członków komisji, w obecnych warunkach rozwoju oświaty i wyzwań przed nią stojących jest daleka od profesjonalizmu, nierzetelna i często błędna.

Badania «Clever: School of Natural and Mathematical Sciences» prowadzone wśród kierowników organów oświaty potwierdzają, że trafność w wyborze skutecznych dyrektorów jest niska. Większość zarządzających szkołami posiada niewysoki poziom wiedzy merytorycznej i umiejętności zawodowych. Także ich predyspozycje osobowe pozostawiają wiele do życzenia i w sposób negatywny odbiją się na jakości pracy szkoły². Jako główne przyczyny takiego stanu rzeczy wskazuje się brak rzetelnych kryteriów i metod oceny podczas konkursu na stanowisko dyrektora szkoły, w wyniku czego funkcje tę pełnią źle wykwalifikowani i niedostatecznie przygotowani pracownicy ${ }^{25}$.

\section{Wnioski i propozycje zmian}

W świetle powyższych rozważań wydaje się, że zarówno w Polsce, jak i w Ukrainie proponowane obecnie procedury konkursu na stanowisko dyrektora szkoły nie spełniają profesjonalnych wymogów wyboru kadry zarządzającej. Umiejętności i predyspozycje kandydatów nie są diagnozowane i konfrontowane z rzeczywistymi wymaganiami stanowiska oraz specyfiką organizacji. Brakuje też obiektywnych wskaźników i metod oceny kandydatów oraz fachowców zasiadających w gronie osób decyzyjnych.

W obu krajach procedura powierzania stanowiska kierowniczego w szkole odbywa się wyłącznie drogą heurystyczną, bez szczegółowej analizy możliwości i zdolności kandydatów. Jak pokazują przywołane powyżej badania, efektywność dyrektorów wybieranych na podstawie obecnego konkursu nie wypada pozytywnie. Podstawową przyczyną takiego stanu rzeczy jest, zdaniem badaczy, zbytni subiektywizm decyzji wynikający z braku sformułowania adekwatnych wymogów i standaryzacji metod oceny, sprzyjający błędnym wyborom i dyskredytacji samej idei tak prowadzonego konkursu.

\footnotetext{
${ }^{24}$ Niewłaściwe cechy osobowe i brak kompetencji społecznych stanowi, zdaniem Nowodworskiej, podstawowe podłoże konfliktu i spadek efektywności pracy szkoły.

${ }^{25}$ Гриб' юк О.О., 2016. Перспективи впровадження варіативних моделей комп'ютерно орієнтованого середовища навчання предметів природничо-математичного циклу у загальноосвітніх навчальних закладах України / Гриб'юк О.О. // Збірник наукових праць Кам'янець-Подільського національного університету імені Івана Огієнка. Серія педагогічна / [редкол.:П.С. Атаманчук (голова, наук. ред.) та ін.] -Кам'янець-Подільський: Кам'янець-Подільський національний університет імені Івана Огієнка, 2016. - Випуск 22: Дидактичні механізми дієвого формування компетентнісних якостей майбутніх фахівців фізико-технологічних спеціальностей. - С. 184-190.
} 
W związku z tym, kluczowe staje się wskazanie i uzasadnienie określonych kryteriów oraz opracowanie metod oceny kandydatów na stanowisko dyrektora szkoły, jeśli chcemy budować profesjonalizm menadżerski w oświacie.

Punktem wyjścia prac nad zmianą w tym zakresie powinna stać się refleksja nad obowiązkami i zadaniami wpisanymi w dyrektorską codzienność. Dalej, warto dokonać analizy kompetencji zawodowych i przywódczych oraz opracować zestaw cech osobowych dyrektora, niezbędnych do pełnienia funkcji kierowaniczej w szkole. Analiza taka powinna zmierzać do wypracowania standardu kwalifikacji/kompetencji, który następnie przełożony zostanie na wskaźniki i metody służące ich ocenie. Wypracowując takie rozwiązania, warto zwrócić uwagę, iż procedura zyska na rzetelności jeśli:

- przy ocenie będzie zastosowane systemowe podejście do zbadania cech zawodowych i psychologicznych kandydatów;

- wybór na stanowisko dyrektora szkoły będzie przeprowadzony z użyciem kryteriów optymalności na drodze wieloetapowego oceniania cech zawodowych i predyspozycji osobowościowych;

- nominacja na stanowisko odbędzie się na podstawie oceny końcowej kandydatów, wydanej przez komisję konkursową składającą się ze specjalistów w dziedzinie zarządzania, psychologii, a także przedstawicieli organów kadrowych kierowania oświatą i szkoły, dla której jest prowadzony konkurs na dyrektora ${ }^{26}$.

W celu realizacji przedstawionych postulatów należy rozwiązać następujące kwestie, jak:

- wykrycie w praktyce pozytywnego doświadczenia mianowania na stanowisko dyrektora szkoły i przeszkód w dobrym rozwiązaniu tego zadania;

- uzasadnienie rekomendacji praktycznych wedtug procedury oceny $i$ doboru kandydatów na dyrektora szkoty;

- opracowanie metod wyboru na stanowisko dyrektora szkoty;

- stworzenie hierarchicznego modelu cech funkcjonalnych i zachowań dyrektora szkoty.

Podstawą proponowanego rozwiązania jest holistyczne podejście do spójnej analizy i oceny zawodowych oraz psychologicznych charakterystyk dyrektora szkoły, w kontekście jego działalności przywódczej i zarządczej.

${ }^{26}$ Autorki mają świadomość, iż wprowadzenie do komisji profesjonalistów z danej dziedziny może znacząco podwyższyć koszty procedury rekrutacyjnej. Warto jednak rozważyć takie rozwiązanie, gdyż daje ono możliwość skorzystania z uprawnień zawodowych i na przykład w przypadku psychologa pozwala na wykorzystanie wystandaryzowanych narzędzi diagnostycznych, co z kolei może znacznie skrócić procedurę, przy jednoczesnym wzroście trafności wyboru. 
Zasadne wydaje się więc, by ocenę kandydatów na stanowisko dyrektora szkoły przeprowadzać na podstawie kolejnego stosowania dwóch kryteriów: kryterium przydatności - charakteryzującego zgodność kandydatów z wymogami stanowiska i kryterium optymalności - określającego pierwszeństwo kandydatów według wynikowego wskaźnika oceny. Jako wynikowy wskaźnik oceny kandydatów na dyrektora można racjonalnie wykorzystać ocenę rangi, charakteryzującą osąd grupowy członków komisji konkursowej w stosunku do każdego kandydata.

Konkretyzację struktury i treści wskaźników oceny kandydatów na stanowisko dyrektora szkoły można oprzeć na naukowym modelu hierarchicznym cech funkcjonalnych ${ }^{27}$. Został on utworzony na podstawie systematyzacji i uogólnienia cech oraz zachowań kierownika metodami uporządkowania lingwistycznego i unifikacji terminów. Bierze on pod uwagę całokształt działalności dyrektora szkoły, a także wymagania podyktowane systemami zewnętrznymi.

Metoda wyboru kandydatów na stanowisko dyrektora szkoły za pomocą opracowanego modelu hierarchicznego cech funkcjonalnych i stosunków zależności funkcjonalnej dyrektora szkoły stanowi dwa kolejne stadia procedury: formalizowane i heurystyczne. Formalizowane zawiera trzy etapy wstępnej oceny kandydatów na stanowisko dyrektora szkoły. W pierwszym, za pomocą kryterium przydatności, oceniana jest zgodność kandydatów odnośnie ograniczonych wymagań (staż pracy pedagogicznej i kierowniczej, wykształcenie i poziom pedagogiczny), w drugim, za pomocą narzędzi diagnostycznych, określane jest znaczenie indywidualnych wskaźników cech i postaw kandydatów, w trzecim, za pomocą kryterium przydatności, oblicza się uogólniony wskaźnik cech i postaw kandydatów, w efekcie podając wstępną ocenę dopasowania do wskazanych kompleksowych wymagań.

Końcowa ocena kandydatów na stanowisko dyrektora szkoły następuje $\mathrm{w}$ toku heurystycznego stadium wyboru, zawierającego cztery etapy: oceniania heurystycznego raportów tematycznych; oceny rozwiązywania zadań kierowniczych oraz sprawności przekazywania poleceń i zarządzeń; rozmów z kandydatami; końcowej oceny komisji, zawierającej finalne opinie grupowe co do pierwszeństwa $\mathrm{w}$ wyznaczeniu kandydatów na stanowisko dyrektora szkoły. Warto przy tym podkreślić, iż z uwagi na decyzyjną rolę komisji, ra-

27 О.О. Гриб'юк, Перспективи впровадження варіативних моделей комп'ютерно орієнтованого середовища навчання предметів природничо-математичного циклу у загальноосвітніх навчальних закладах України / Гриб'юк О.О. / / Збірник наукових праць Кам'янець-Подільського національного університету імені Івана Огієнка. Серія педагогічна / [редкол.: П.С. Атаманчук (голова, наук. ред.) та ін.] - Кам'янець-Подільський: Кам' янець-Подільський національний університет імені Івана Огієнка, 2016. - Випуск 22: Дидактичні механізми дієвого формування компетентнісних якостей майбутніх фахівців фізико-технологічних спеціальностей. - С. 184-190. 
cjonalne wydaje się, by w jej szeregach znaleźli się specjaliści z wybranych dziedzin kierunkowych.

Tworzenie komisji konkursowych złożonych z fachowców i przeprowadzenie pełnej oceny kandydatów jest konieczne nie tylko w przypadku zgłoszenia kilku (kilkunastu) kandydatów na stanowisko dyrektora, ale także kiedy w konkursie startuje tylko jeden człowiek. W takiej sytuacji przeprowadzenie pełnej oceny pretendenta umożliwia wskazanie jego (nie)kompetencji i stwarza możliwość uzupełnienia braków, czy korekty postaw ${ }^{28}$.

W świetle powyższych rozważań zasadne wydaje się, aby dalsze prace badawcze oraz legislacyjne prowadzić w dwóch zasadniczych kierunkach: po pierwsze - uściślania kryteriów kompetencyjnych kierowników, po drugie - potrzeby uzupełnienia i uzasadnienia części metodycznej i treściowej procedury oceniania tak, aby można było nie tylko obiektywniej dokonywać wyboru najlepszych liderów, ale również przeprowadzać atestację już pracujących dyrektorów szkół.

W związku z doniosłą rolą, jaką oświata odgrywa w kształtowaniu postaw jednostki i potencjału społeczno-gospodarczego każdego społeczeństwa, wydaje się konieczne, aby tak ważną instytucją jaką jest szkoła zarządzali najlepsi menadżerowie. Dopiero wówczas będzie ona w stanie sprostać pokładanym w niej nadziejom. By tak się stało niezbędne jest bardziej refleksyjne oraz metodyczne spojrzenie na kwestie dotyczące wyboru osób zarządzających szkołami i w miarę możliwości tworzenie rozwiązań sprzyjających optymalizacji oraz profesjonalizacji tego procesu.

\section{BIBLIOGRAFIA}

Banaszak S., Edukacja menedżerska w społeczeństwie współczesnym. Studium teoretyczno-empiryczne, Wydawnictwo Naukowe UAM, Poznań 2011.

Dorczak R., Mazurkiewicz G. (red.), Przywództwo edukacyjne. Próba zmiany, Wydawnictwo Uniwersytetu Jagiellońskiego, Kraków 2015.

Габдуллин Г.Г., Школоведение. Курс лекций по педагогике, Казань 1997.

Gawrecki L., Kompetencje menedżera oświaty: poradnik dla dyrektorów szkót i innych placówek edukacyjnych oraz pracowników prowadzących i nadzorujących, eMPi2, Poznań 2003.

Gawroński K., Potyczki prawne dyrektora szkoty. Rola prawa w wybranych obszarach zarzadzania szkoła, Wolters Kluwer, Warszawa 2010.

Gawroński K., Stefan A., Zarządzanie placówką oświatową, Dom Wydawniczy ABC Grupa Wolters Kluwer, Warszawa 2008.

${ }^{28}$ Doświadczalne sprawdzenie proponowanego rozwiązania pozwoliło potwierdzić znaczenie wymaganego poziomu wskaźnika uogólnionego oceny $(\mathrm{Wtp}=0,63)$ oraz określić u każdego z badanych te cechy i stosunki, które są niedostatecznie rozwinięte i wymagają korekty (O. Hrybik, 2016). 
Гриб'юк О.О., Перспективи Впровадження Варіативнихмоделей комп'ютерно орієнтованого середовища навчання предметів природничо-математичного ииику у загальноосвітніх навчальних закладах України / Гриб'юк О.О. / / Збірник наукових праць Кам'янець-Подільського національного університету імені Івана Огієнка. Серія педагогічна / [редкол.: П.С. Атаманчук (голова, наук. ред.) та ін.] - Кам'янець-Подільський: Кам'янець-Подільський національний університет імені Івана Огієнка, 2016. Випуск 22: Дидактичні механізми дієвого формування компетентнісних якостей майбутніх фахівців фізико-технологічних спеціальностей. - С. 184-190.

Jeżowski A.J., Madalińska-Michalak J., Dyrektor szkoły - koncepcje i wyzwania. Między teoria i praktyka, ORE, Warszawa 2015.

Каменский A.М., Директор школы - ключевая фигура педагогических инноваций: [Електронний ресурс], Режим доступа: http//www. Likt590.ru. 2.

Komorowski T., Dyrektor szkoły. Pracodawca, menedżer, pracownik, eMPi2, Poznań 2008.

Kwiatkowski S.M., Kwalifikacje zawodowe nauczycieli - wciaż otwarty problem badawczy, Edukacja, 2004, 4.

Kwiatkowski S.M., Problemy terminologiczne w procedurach standaryzacji kwalifikacji zawodowych, [w:] Kwalifikacje zawodowe na wspótczesnym rynku pracy, red. S.M. Kwiatkowski, Instytut Badań Edukacyjnych, Warszawa 2004.

Масааки И., Кайдзен: ключ к успеху японских компаний, М.: ЮНИТИ - ДАНА, 2004.

Mazurkiewicz G. (red.), Jak budować dobra szkotę? Potencjat i bariery ewaluacji, Wydawnictwo Uniwersytetu Jagiellońskiego, Kraków 2015.

Mazurkiewicz G., Przywództwo edukacyjne. Odpowiedzialne zarządzanie edukacją wobec wyzwań wspótczesności, Wydawnictwo Uniwersytetu Jagiellońskiego, Kraków 2011.

Pielachowski J., Organizacja, kierowanie i nadzór pedagogiczny w szkole. Poradnik dla dyrektorów szkót oraz pracowników organów prowadzących i nadzorujących szkoły, eMPi2, Poznań 2009.

Сухомлинський В.О., Вибрані твори в 5-ти m. t. 4. / В.О.Сухомлинський. - Київ 1976/1977.

Szafran J., Zarządzanie w oświacie a kompetencje psychologiczne dyrektorów, Zarządzanie Publiczne, 2018, 1(41).

Witek S., Zarzadzanie zreformowana szkoła, Wydawnictwo Naukowe PWN, Warszawa 2000.

Ямбург Е.А., Отсутствие грамотной стратегии образования - угроза национальной безопасности // Народное образование, 2012, 6.

AT\&T - http://about.att.com/content/csr/home/possibilities/at-t-aspire.html

北青网，(2017-11-09). 138万人通过国考审核创7年之最 119个职位无人报 -http://sh.qihoo.com/pc/detail?url=http\%3A \% 2F\% 2Ffawen.news.so.com \% 2F510609c45eb2013eaeb6f46dca86ea84\&check=b88c8741e6addfa5\&uid=e325af10fcd8b9544de33cc9643032f9\&sign=360_79aabe15.

Rozporządzenie Ministra Edukacji Narodowej z 11 sierpnia 2017 r. w sprawie wymagań, jakim powinna odpowiadać osoba zajmująca stanowisko dyrektora oraz inne stanowisko kierownicze w publicznym przedszkolu, publicznej szkole podstawowej, publicznej szkole ponadpodstawowej oraz publicznej placówce (DzU 2017, poz. 1597).

Rozporządzenie Ministra Edukacji Narodowej z dnia 11 sierpnia 2017 r. w sprawie regulaminu konkursu na stanowisko dyrektora publicznego przedszkola, publicznej szkoły podstawowej, publicznej szkoły ponadpodstawowej lub publicznej placówki oraz trybu pracy komisji konkursowej (DzU 2017, poz. 1587).

Постанова Кабінету Міністрів України від 13 жовтня 2015 р. № 827 «Про затвердження Порядку призначення на посаду керівників загальноосвітніх навчальних 
закладів державної форми власності». Точка доступу - https://www.kmu.gov. ua/ua/npas/248564119

Закон України від 13.05.1999 р. № 651-XIV «Про загальну середню освіту» (Відомості Верховної Ради України (ВВР), 1999, № 28, ст.230). Документ 651-14, чинний, поточна редакція - Редакція від 28.09.2017, підстава 2145-19. Точка доступу http:// zakon3.rada.gov.ua/laws/show/651-14

Постанова Кабінету Міністрів України від 27.08.2010 № 778 «Про затвердження Положення про загальноосвітній навчальний заклад». Перелік Документ 7782010-п, чинний, поточна редакція - Редакція від 12.08.2017, підстава 576-2017-п. Точка доступу - http:/ / zakon3.rada.gov.ua/laws/show/778-2010-\%D0\%BF

Наказ Міністерства освіти і науки України від 06.10.2010 № 930 «Про затвердження Типового положення про атестацію педагогічних працівників». Документ z125510, чинний, редакція від 30.09.2013, підстава z1417-13. Точка доступу - http:/ / zakon5.rada.gov.ua/laws/show/z1255-10

Закон України від 14.10.2014 № 1700-VII «Про запобігання корупції» (Відомості Верховної Ради (ВВР), 2014, № 49, ст.2056). Документ 1700-18, чинний, поточна редакція - Редакція від 03.08.2017, підстава 2136-19. Точка доступу - http:/ / zakon3.rada.gov.ua/laws/show/1700-18

Постанова Кабінету Міністрів України від 13 жовтня 2015 р. № 827 «Про затвердження Порядку призначення на посаду керівників загальноосвітніх навчальних закладів державної форми власності». Точка доступу - https://www.kmu.gov. ua/ua/npas/248564119; Закон України від 13.05.1999 р. № 651-XIV «Про загальну середню освіту» (Відомості Верховної Ради України (ВВР), 1999, № 28, ст.230). Документ 651-14, чинний, поточна редакція - Редакція від 28.09.2017, підстава 2145-19. Точка доступу - http:/ / zakon3.rada.gov.ua/laws/show/651-14

Постанова Кабінету Міністрів України від 27 грудня 2017 р. № 1094 «Про затвердження Порядку проведення конкурсу на зайняття посади керівника державного, комунального закладу охорони здоров'я». Документ 1094-2017п, чинний, поточна редакція - Редакція від 05.05.2018, підстава 316-2018-п. Точка доступу - http:/ / zakon3.rada.gov.ua/laws/show/1094-2017-\%D0\%BF 